\title{
PENGERTIAN PEMBUKTIAN DI PENGADILAN TATA USAHA NEGARA
}

\author{
WEMPI REFORMASI \\ wempi0309@gmail.com \\ 1910003600352 \\ UNIVERSITAS EKA SAKTI PADANG
}

\section{A. PENDAHULUAN}

Dalam menyelesaikan sengketa / perkara tata usaha negara, pidana, sebelum hakim menjatuhkan atau mengambil putusan untuk mencari suatu kebenaran baik kebenaran materil maupun kebenaran formil bahwa hakim terlebih dahulu harus memeriksa alat-alat bukti yang diajukan para pihak. Pembuktian yang dilakukan oleh hakim dalam mengadili sengketa/perkara adalah untuk menentukan hubungan hukum yang sebenarnya terhadap pihak-pihak. Tidak hanya kejadian atau peristiwa saja yang dapat dibuktikan tetapi ada sesuatu hak juga yang dibuktikan malahan dalam sengketa tata usaha negara yang dibuktikan adalah suatu keabsahan dari perbuatan pejabat tata usahanegara.

Menurut Teguh Samudera, bahwa masalah pembuktian penting sekali diketahui oleh seluruh masyarakat masyarakat dan oleh karena itu perlu pula untuk disebar luaskan agar masyarakat lebih jelas memahahi masalah pembuktian dengan alasan pertimbangan sebagai berikut:

a. Pada dasarnya pembuktian adalah merupakan bagian yang penting dalam hukumacara.

b. Baik dalam mengadili perkara hakim selalu memerlukanpembuktian.

c. Dengan diselesaikannnya suatu perkara melalui Pengadilan maka akan dicapai suatu penyelesaian yang pasti berdaarkan alat-alatpembuktian.

d. Karena dengan pembuktian dimaksudkan akan dapat dicapai suatu kebenaran yang sesungguhnya yaitu kebenaran dari hubungan hukumapihak-pihak yang berperkara.

e. Dan dengan jalan pembuktian maka akan dapat diketahui siapa sebenarnya yangbenar. 
f. Dan dengan adanya pembuktian maka akan dapat dijamin adanya perlindungan terhadap hak-hak asasi para pihak yang berperkara secara seimbang.

g. Oleh karena dengan pembuktian dapat memberikan gambaran bahwa pemeriksaan suatu perkara adalah pemeriksaan yang benar menurut hukum.

h. Adanya alat alat pembuktian itu dapat menjamin bahwa hakim dalam melakukan pembuktian tidak mengada-ada karena telah ditentukan dalam undang-undang.

i. Adalah suatu kenyataan yang tidak dapat dipungkiri bahwa masih ada sarjana hukum yang belum tahu bagaimana cara membuktikan suatu hal yang didalilkan.

Menurut Pasal 24 UUD 1945 yang di amandemen. menentukan (1)Kekuasaan kehakiman merupakan kekuasaan yang merdeka untuk menyelengggarakan peradilan guna menegakan keadilan; (2)kekuasaan kehakiman dilakukan oleh sebuah Makamah Agung dan badan peradilan yang berada di bawahnya, dalam lingkungan peradilan umum, lingkungan peradilan agama, lingkungan peradilan militer, lingkungan peradilan tata usaha negara dan sebuah Makamah Konstitusi.

Menurut Pasal 24 UUD 1945 yang di amandemen, berarti di Indonesia kekuasaan yudicatif terdiri dari :
a. Lingkungan PeradilanUmum
b. Lingkungan PeradilanAgama
c. Lingkungan PeradilanMiliter
d. Lingkungan Peradilan Tata UsahaNegara
e. MakamahKonstitusi

Di mana dalam pelaksanaan operasionalnya dan hukum acaranya bahwa lembaga ini diatur menurut undang-undang tersendiri.

Dalam proses pemeriksaan sengketa tata usaha negara ada persamaan dan perbedaan dengan pemeriksaan perkara pidana, perbedaannya dalam pemeriksaan 
sengketa tata usaha negara ada yang dinamakan pemeriksaan persiapan.Proses pemeriksaan persiapan dilakukan sebelum adanya pemeriksaan di persidangan yang tertutup ( tidak terbuka untuk umum ) dalam pemeriksaan ini langsung diketuai oleh Ketua Pengadilan Tata Usaha Negara. Dari hasil pemeriksaan ini maeles hakim akan memberikan putusan sesuai dengan ketentuan peraturan perundang-undangan. Sedangkan dalam perkara pidana tidak dikenal pemeriksaan persiapan karena dalam perkara pidana tidak ada permohonan yang dimasukan pihak yang dirugikan, proses persidangan mulai dari berita acara dari kepolisian naik kepada kejaksaan dan dari kejaksaan naik proses ke pengadilan yaitu Pengadilan Negeri.

Dalam pemeriksaan sengketa tata usaha negara sebelum sampai kepada putusan hakim yang sifatnya incchrah bahwa putusan hakim tersebut harus berdasarkan kepada alat alat bukti yang diatur dalam Pasal 100 UU No. 5 Tahun 1986 tentang Peradilan Tata Usaha Negara (selanjutnya disebut UUPTUN). Dalam pemeriksaan alat bukti ini walaupun pemeriksaaan sengketa tata usaha negara hampir sama dengan pemeriksaan perkara pidana dalam penmeriksaan alat bukti mempunyai suatu perbedaan yang signifikan, karena dalampemeriksaan alat-alat bukti ada asas-asas yang terdapat dalam peradilan tata usaha negara dan asas ini tidak ditemukan dalam penyelesaian perkara pidana. Karena masalah pembuktian ini supaya diketahui oleh masyarakat maka penulis akan menguraikan secara sederhana sesuai dengan peraturan perundang-undangan yang berlaku tentang pembuktian penyelesaian sengketa tata usaha negara dan perkara pidana.

\section{B. PEMBAHASAN}

1. Pembuktian Penyelesaian Sengketa Tata Usaha Negara.

Yang dimaksud dengan hukum pembuktian adalah hukum yang mengatur tentang tata cara untuk menetapkan terbuktinya fakta yang menjadi dasar hukum dari pertimbangan dalam menjatuhkan suatu putusan. Menurut Indroharto fakta tersebut terdiri fakta berikut : 
a. Fakta hukum,yaitu kejadian-kejadian atau keadaan-keadaan yang eksistensi (keberadaannnnya) tergantung dari penerapan suatu peraturan perundang-undangan.

b. Fakta biasa, yaitu kejadian-kejadian atau keadaan-keadaan yang juga ikut menentukan adanya fakta hukum tertentu.

Pasal 100 ayat (2) UUPTUN menentukan bahwa kejadian yang telah diketahui umum,tidak perlu dibuktikan. Dari ketentuan tersebut dapat diketahui bahwa yang telah diketahui oleh umum jika dijadikan sebagai dasar pertimbangan oleh hakim dalam mengambil keputusan, fakta tersebut tidak perlu dibuktikan. Menurut Indroharto disamping fakta yang diketahui umum ada juga fakta yang dapat menjadi dasar pertimbangan hakim dalam menjatuhkan putusannya yang tidak perlu dibuktikan, yaitu :

a. hal-hal yang menurut pengalaman umum selaluterjadi

b. fakta yang prosesual yang terjadi selamapemeriksaan

c. eksistensihukum

a. 1.Alat-alat bukti Dalam Pemeriksaan Sengketa Tata Usaha Negara

Pengaturan tentang alat-alat bukti dalam Hukum Acara peradilan Tata Usaha Negara diatur dalam Pasal 100 sampaipasal 107 UUPTUN. Menurut Pasal 100 ayat (1) UUPTUN alat bukti adalah:

a. surat atautulisan

b. keterangan ahli

c.keterangan saksi

d. pengakuan para pihak

e.pengetahuan Hakim

\section{a. Surat atau Tulisan.}


Menururt Sudikno Mertokusumo, yang dimaksud dengan surat atau tulisan adalah segala sesuatu yang memuat tanda-tanda bacaan yang dimaksudkan untuk mencurahkan isi hati atau untuk menyampaikan buah pikiran seseorang dan dipergunakan sebagai pembuktian.

Pasal 101 UU No. 5 tahun1986 Surat sebagai alat bukti terdiri atas 3 jenis yaitu :

a. Akta otentik, yaitu surat yang dibuat oleh atau dihadapan seorang pejabat umum yang menurut peraturan perundang- undangan berwenang membuat surat yang dimaksud untuk dipergunakan sebagai alat bukti tentang peristiwa atau peristiwa hukum yang tercantum didalamnya.

b Akta dibawah tangan, yaitu surat yang dibuat dan ditanda tangan oleh pihak yang bersangkutan dengan maksud untuk dipergunakan sebagai alat bukti tentan peristiwa atau peristiwa hukum yang tercamtum didalamnya.

c Surat-surat lain yang bukan akta.

Menurut Indroharto, termasuk dalam pengertian surat atau tulisan adalah hasil dari pemeriksaan persiapan guna mematangkan perkara yang bersangkuatan dalam pemeriksaan dimuka sidang.

\section{b. Keterangan Ahli.}

Alat bukti ini diatur dalam Pasal 102 UU No. 5 Tahun 1986 :

Ayat (1), yang menentukan, keterangan ahli adalah pendapat orang yang diberikan dibawah sumpah dalam persidangan tentang hal yang ia ketahui menurut pengalaman dan pengetahuannnya.

Ayat (2) Seseorang tidak boleh didengar sebagai saksi berdasarkan Pasal 88 tidak boleh memberikan keterangan ahli.

Orang yang tidak boleh membeikan kesaksian dalam persidangan sebagaimana dimaksud dalam Pasal 88 yaitu :

a. keluarga sedarah atau semenda menurit garis keturunan lurus ke atas atau ke bawah sampai derajat kedua dari salah satu pihak yang bersengketa

b. istri atau suami dari pihak yangbersengketa.

c. anak yang belum berusia tujuh belas tahun 
d. orang yang sakitingatan

Sebagaimana yang diatur dalam Pasal 103 ayat (1 dan 2 ), atas permintaan kedua belah pihak atau salah satu pihak atau karena jabatannya , Hakim ketua sidang dapat menunjuk seorang atau beberapa orang saksi ahli, Dan ahli yang memberikan keterangan dalam persidangan harus memberikan keterangan, baik dengan surat maupun dengan lisan yang dikuatkan dengan sumpah atau janji menurut kebenaran sepanjang pengetahuannya yang sebaik-baiknya.

Berdasarkan ketentuan tersebut di atas bahwa saksi ahli tidak mutlak diuinculkan dalam persidangan, saksi ini muncul apabila diajukan oleh para pihak atau menurut hakim memang diperlukan saksi ahli.

Sebagaimana yang diatur dalam pasal 103 ini bahwa seorang ahli dalam persidangan memberikan keterangan tidak hanya berbentuk lisan tetapi juga bisa berbentuk tulisan. Menurut pendapat penulis bahwa yang diutamakan adalah yang berbentuk lisan karena makna dari kata didengar keterangannya, sesuai dengan pegetahuan dan pengalaman lebih mengarah kepada lisan, dan tulisan untuk menguatkan keterangan lisan sebagai alat bukti dari kerengan ahli unntuk meyakinkan hakim dan kedua belah pihak.

Indroharto mengemukakan, bahwa seorang ahli dapat dipanggil dimuka persidangan untuk memberikan keterangan di bawah sumpah tentang penegetahuanya mengenai suatu fakta. Maksudnya bahwa seseorang yang dihadapkan di persidangan sebagai saksi ahli adalah orang yang memberikan keterangan sesuai dengan keahlian yangdimililkinya.

\section{c Keterangan saksi}

Pasal 104 UU No. 5 tahun 1986 , menentukan keterangan saksi dianggab sebagai alat bukti apabila keterangan itu berkenaan dengan hal yang dialami,dilihat,atau didengar oleh saksi.

Dari ketentuan yang terdapat dalam dalam Pasal 104 tersebut dapat diketahui bahwa saksi adalah orang yang dapat memberikan keterangan tentang sesuatu hal yang dialaminya, dilihat atau didengarnya tentang sengketa yang diperiksa dipengadilan. 
Dalam memberikan keterangan di muka persidangan tidak semua orang yang bisa dihadapkan sebagai saksi. Hal ini diatur dalam Pasal 88 dan 89 UU No. 5 Tahun 1986 siapa saja yang tidak boleh dihadirkan sebagai saksi dalam pemeriksaan sengketa tata usaha negara. Oleh Indroharto yang dimaksud dengan keterangan saksi itu adalah keterangan yang didengar oleh hakim selama pemeriksaan perkara dilakukan.

\section{d. Pengakuan ParaPihak}

Pasal 105 , menentukan Pengakuan para pihak tidak dapat ditarik kembali kecuali berdasarkan alasan yang kuat dan dapat diteriam olehhakim.

Menurut Wiyono (2013) pengakuan yang diberikan oleh pihak penggugat atau tergugat belum tentu menunjukan kebenaran materil yang berkaitan dengan terjadinya sengketa tata usaha negara, oleh karena itu meskipun penggugat atau tergugat telah memberikan pengakuan, tetapi hakim masih mempunyai wewenang untuk meneliti lebih lanjut terhadap pengakuan yang diberikan parapihak.

\section{e. Pengetahuan Hakim}

Pasal 106 UU PTUN, menentukan bahwa yang dimaksudkan dengan pengetahuan hakim adalah hal olehnya diketahui dan diyakini kebenarannya.

Pengetahuan hakim tersebut adalah pengetahuan dari hakim yang diperoleh selama pemeriksaan dalam persidangan yang berlangsung. Menurut Wijono yang termasuk pemeriksaan di sidang pengadilan adalah pemeriksaan setempat ( gerechtelijke plaatselijk onderzoek ), karena hanya tempat sidang saja yang pindah, tidak lagi dikantor Peradilan Tata Usaha Negara, tetapi misalnya di kantor Tergugat.

\section{a..2 Asas Pemeriksaan Alat-Alat Bukti Dalam Pemeriksaan Sengketa Tata Usaha Negara.}

Menurut Subekti dikutip Rozali Abdullah (1992) Suatu masalah yang sangat penting dalam hukum pembuktian adalah masalah beban pembuktian, pembagian beban pembuktian ini harus dilakukan dengan adil dan tidak berat sebelah karena suatu pembagian beban pembuktian yang berat sebelah berarti menjerumuskan pihak yang menerima beban yang terlampau berat dalam jurang kekalahan.

Penjelasan Umum UU No. 5 Tahun 1986, menyatakan bahwa Hukum Acara yang digunakan pada Peradilan Tata Usaha Negara mempunyai persamaan dengan hukum acara 
yang digunakan pada Peradilan Umum untuk perkara pidana : Pada peradilan Tata Usaha Negara, Hakim berperan lebih aktif dalam proses persidangan guna memperoleh kebenaran materil dan untuk itu undang-undang mengarah pada pembuktian bebas sebagai mana yang diatur dalam pasal 107 UU No. 5 tahun1986.

Menurut Sudikno dikutip Wiyono, ajaran pembuktian bebas atau teori pembuktian bebas adalah ajaran atau teori yang tidak menghendaki adanya ketentuan-ketentuan yang mengikat hakim, sehinggga sejauhmana pembuktian dilakukan diserahkan kepadahakim.

Apa sebab yang diikuti adalah ajaran pembuktian bebas, karena proses pemeriksaan di sidang pengadilan terhadap sengketa tata usaha negara yang diatur dalam UU N0.5 tahun 1986 jo UU No.9 Tahun2004 jo. UU no.51 Tahun 2009 menurut pembuat undang-undang dimaksudkan untuk memperoleh kebenaran materil dan bukan kebenaran formil.

Pasal 107, UU No. 5 tahun 1986, menyatakan Hakim menentukan apa yang harus dibuktikan, beban pembuktian beserta penilaian pembuktian dan untuk syahnya pembuktian diperlukan sekurang-kurangnya dua alat bukti berdasarkan keyakinanhakim.

Dalam penjelasan pasal ini disebutkan bahwa pasal ini merupakan ketentuan dalam rangka usaha menemukan kebenaran materil. sama dengan system Hukum Pembuktian dalam HukumAcara Pidana, maka dengan memperhatikan segala sesuatu yang terjadi dalam pemeriksaan tanpa bergantung pada fakta dan hal yang diajukan oleh para pihak, Hakim Peradilan Tata Usaha Negara dapat menentukan sendiri:

a apa yang harusdibuktikan

b. siapa yang harus dibebani pembuktian, hal apa yang harus dibuktikan oleh pihak yang berpekara dan hal apa saja yang harus dibuktikan oleh Hakimsendiri.

c. alat bukti mana saja yang diutamakan untuk dipergunakan dalampembuktian

d. kekuatan pembuktian yang telahdiajukan

\section{a apa yang harusdibuktikan.}

Penjelasan pasal 107 Undang-undang No. 5 Tahun1986 menyatakan dalam proses pemeriksaan di sidang Pengadilan Hakim tidak tergantung atau tidak terikat pada fakta dan hal yang diajukan Penggugat atau Tergugat. Jika para pihak di sidang pengadilan 
berharab fakta dan hal yang diajukan dapat memperoleh perhatian hakim maka fakta tersebut harus dibuktikan kebenarannya.

\section{b. Siapa yang harus dibebankanpembuktian.}

Menurut Wijono ( 2013) yang dimaksud dengan beban pembuktian adalah kewajiban yang dibebankan kepada suatu pihak untuk membuktikan fakta yang menjadi dasar pertimbangan dari hakim dalam menjatuhkan putusannya.

Dalam UU No. 5 Tahun 1986 tidak ada mengatur tentang dalil pembuktian , dalam Pasal 107 hanya menyebutkan hakim menentukan apa yang harus dibuktikan, beban pembuktian beserta penilaian pembuktian dan untuk sahnya pembuktian diperlukan sekurang-kurangnya dua alat bukti berdasarkan keyakinan hakim. Dengan demikian sesuai dengan asas pemeriksaan sengketa tata usaha negara dimana hakim harus aktif dalam pemeriksaan dipersidangan, maka dalam memeriksa dan memutus dan menyelesaikan sengketa tata usaha negara hakim mepunyai kewenangan untuk menentukan siapa yang harus dibebani pembuktian.

\section{c. Apa yang harus dibuktikan.}

Mengenai apa yang harus dibuktikan, hal ini sudah ditentukan dalam Pasal 100 ayat (1) UU No. 5 Tahun 1985 tentang- jenis alat bukti. Menurut Indroharto alat-alat bukti yang diatur dalam pasal tersebut mempunyai derajat bobot yang sama, artinya tidak ada tingkatan mengenai kekuatan pembuktian dari masing-masing alat bukti tersebut atau tidak ada perbedaan kekuatan pembuktian antara alat bukti yang satu dengan yang lainnya.

Apabila dihubungkan dengan Pasal 107, dalam memeriksa, memutus dan menyelesaikan sengketa tata usahga negara hakim mempunyai wewenang untuk memilih alat bukti tertentu diantara alat-alat bukti sebagaimana ditentukan dalam Pasal 100 ayat (1)

untuk memberikan penilaian tentang kekuatan pembuktian dari alat bukti tersebut untuk dipergunakan dalam pembuktian. 


\title{
d. Kekuatan Pembuktian.
}

Mengenai kekuatan pembuktian yang diajukan, dalam Pasal 107 sudah jelas jelas disebutkan bahwa hakim dapat menentukan sendiri kekuatan pembuktian. Maksudnya bahwa hakim mempunyai kewenangan untuk memberikan penilaian terhadap hasil pembuktian ,hanya saja untuk memberikan penilaian terhadap hasil pembuktian hakim harus memperhatikan pembatasan sebagaimana ditentukan dalam Pasal 107 , yaitu untuk sahnya pembuktian diperlukan sekuran-kurang dua alat bukti berdasarkan keyakinanhakim.

\section{II.b. Pembuktian Dalam Perkara Pidana}

\author{
Menurut Satochid Karta Negara dalam Teguh Samudera dalam bidang \\ hukum pembuktian dikenal empat sistem atau empat ajaran; \\ a Negatief Wettelijk Bewijjsleer/ Bewijs Theori \\ b. Positief Wettelijk Bewijsleer/Bewijs Teori \\ c. Conviction In Time (Bloot Gemooedelijkke Overtuiging) \\ d.ConvictionRaissonnee(BeredenneerdeOvertuiging)
}

ad.a. Negatief Wettelijk Bewijsleer

Menurut ajaran ini negatief artinya dengan alat-alat pembuktian yang diakui undang-undang saja belum cukup tapi masih dibutuhkan keyakinan hakim. Denganperkataan lain walaupun cukup pembuktian yang didasarkan kepada alat-alat bukti yang diakui undang-undang, tetapi jika hakim tidak mendapatkan keyakinan, maka terdakwa harus dibebaskan.

\section{Ad.b. Positief Wettelijk Bewijsleer/Bewijs Theorie}

Cara pembuktian yang didasarkan semata-mata atas alat bukti yang diakui sah oleh undang-undang. Menurut ajaran ini cukup alat bukti yang diakui undang- 
undang saja, ini Positif dengan perkataan lain tidak dibutuhkan alat-alat bukti lain dalam hal ini keyakinan hakim.

Ad.c. Conviction In Time ( Bloot Gemooedelijkke Overtuiging)

Cara pembuktian yang didasarkan semata-mata kepada keyakinan hakim tidak dibutuhkan alat-lat bukti lainnnya. Bloot : semata- mata. Gemoedelijkke; keyakinan. Jadi kalua disidang pengadilan hakim telah yakin kepada kesalahan terdakwa maka harus dijatuhkanhukuman.

\section{Ad.d..ConvictionRaissonnee(BeredenneerdeOvertuiging) ajaran} pembuktian :

b. Keyakinan Hakim; tapi keyakinan Hakim ini harusdiberi:

c. alasan-alasan apa sebabnya ia yakin( beredeneerde) dan dasar alasan-alasan ini tidak terikat kepada alat pembuktian yang diakui undang-undang saja tetapi dapat juga dipergunakan alat bukti lain diluarundang-undang. ${ }^{6}$

Sebagaimana telah diuraikan di atas mengenai system pembuktian, maka system pembuktian negatif tersebut terkandung dalam Pasal 294 ayat

HIR, yang berbunyi :

Tidak seorang pun boleh dikenakan hukuman, selain jika hakim mendapat keyakinan dengan alat bukti yang sah, bahwa benar telah terjadi perbuatan yang dapat dihukum dan bahwa orang yang dituduh itulah yang salah tentang perbuatan itu.

Jadi pada pokoknya untuk dapat mempersalahkan seseorang terdakwa diharuskan adanya:

a. Keyakinanhakim

alat-alat pembuktian yang sah, bahwa benar telah terjadi perbuatan yang dapat dihukum dan orang yang dituduhlah yang melakukannnya. 
b. Dengan demikian dalam pembuktian perkara pidana yang menentukan adalah keyakinan hakim, walaupun banyak terdapat alat bukti kalau hakim tidak yakin akan kesalahan terdakwa maka hakim harus membebaskannya. Sesuai dengan tujuan yang dianut dalam hukum pidana yaitu untuk menjatuhkan pidana yang setimpal kepada sipembuat tindak pidana untuk kepentingan umum guna menjaga ketentraman masyarakat dan negara, maka sudah tepat system pembuktian negatif yang dipakai dalam Hukum Acara Pidana.

Menurut Pasal 295 HIR ,dalam Hukum Acara Pidana jenis-jenis alat bukti terdiridari;

1. Keterangansaksi,

2. surat-surat

\section{Pengakuan}

\section{Tanda-tanda/penunjukan}

Adapun sistem Pembuktian yang diatur dalam KUHAP tercantum dalam Pasal 183 yang rumusannya adalah sebagai berikut : "Hakim tidak boleh menjatuhkan pidana kepada seseorang kecuali apabila sekurang-kurangnya dua alat bukti yang sah, ia memperoleh keyakinan bahwa suatu tindak pidana benar-benar terjadi dan bahwa terdakwa yang bersalah melakukannya." Dari rumusan Pasal 183 tersebut, terlihat bahwa pembuktian harus didasarkan sedikitnya pada dua alat bukti yang sah, disertai dengan keyakinan hakim yang diperoleh dari alat-alat bukti tersebut. Artinya, tersedianya minimum dua alat bukti saja,belumcukupuntukmenjatuhkanpidanakepadaterdakwa.

Sebaliknya, meskipun hakim sudah yakin terhadap kesalahan terdakwa, maka jika tidak tersedia minimum dua alat bukti, hakim juga belum dapat menjatuhkan pidana terhadap terdakwa. Dalam hal inilah penjatuhan pidana terhadap seorang terdakwa haruslah memenuhi dua syarat mutlak, yaitu alat bukti yang cukup dan keyakinan hakim. Sistem pembuktian tersebut terkenal dengan nama sistem negative wettelijk.Dalam Penjelasan Pasal 183 KUHAP tersebut dinyatakan bahwa Pembentuk Undang Undang telah menentukan pilihan bahwa sistem pembuktian yang paling tepat dalam kehidupan penegakan hukum di Indonesia adalah sistem pembuktian menurut 
undang-undang secara negatif, semi tegaknya keadilan, kebenaran dan kepastian hukum. Karena dalam sistem pembuktian ini, terpadu kesatuan penggabungan antara sistem conviction-in time (sistem pembuktian yang hanya bersandar atas keyakinan hakim) dengan sistem pembuktian menurut undang-undang secara positif (positief wettelijkstelsel).

Ketentuan dalam Pasal 183 KUHAP tersebut hampir identik dengan ketentuan dalam Pasal 6 UU Nomor 4 Tahun 2004 tentang Kekuasaan Kehakiman yaitu :

“Tidak seorang pun dapat dijatuhi pidana, kecuali apabila pengadilan karena alat pembuktian yang sah menurut undang-undang mendapat keyakinan bahwa seseorang yang dianggap dapat bertanggung jawab, telah bersalah atas perbuatan yang didakwakan atas dirinya. ${ }^{7}$

Oleh karena itu, konsep keyakinan hakim tersebut baru dapat terbentuk dengan didasarkan pada adanya alat bukti yang sah menurut KUHAP. Keyakinan hakim yang akan terbentuk tersebut pada akhirnya nanti hanya terdiri dari dua macam, yaitu keyakinan bahwa terdakwa tidak terbukti bersalah atau sebaliknya keyakinan bahwa terdakwa terbukti bersalah.

Aktualisasi dari kombinasi kedua konsep dalam ketentuan pasal 183 KUHAP tersebut dapat dilihat dalam rumusan kalimat baku setiap diktum putusan perkara pidana yang menyatakan "secara sah dan meyakinkan". Kata "sah" dalam hal ini berarti bahwa hakim dalam memberikan putusan tersebut didasarkan pada alat bukti yang sah sebagaimana diatur dalam KUHAP dan peraturan perundang-undangan lainnya. Sedangkan kata "meyakinkan" dalam hal ini berarti bahwa dari alat bukti yang sah tersebut maka terbentuk keyakinan hakim.( LP3 M AdilIndonesia)

Rumusan sistem pembuktian tersebut tentunya untuk mendukung tujuan dari hukum acara pidana, yaitu untuk mencari dan memperoleh kebenaran materiil. Dengan tercapainya kebenaran materiil maka akan tercapai pula tujuan akhir hukum acara pidana, yaitu untuk mencapai suatu ketertiban, ketentraman, keadilan dan kesejahteraan dalam masyarakat.Adapun yang dimaksud dengan alat-alat bukti yang sah adalah sebagaimana ditentukan dalam Pasal 184 KUHAP, yaitu :

a. keterangansaksi; 
b. keteranganahli;

c. surat;

d. petunjuk;

e. keteranganterdakwa.

Dengan demikian, untuk dapat menjatuhkan pemidanaan kepada seseorang haruslah terdapat minimal dua alat bukti dari lima alat bukti yang diatur dalam Pasal 184 KUHAP yang mengatur secara limitatif alat bukti yang sah menurut undang-undang. Hal tersebut diatas, juga mengisyaratkan bahwa KUHAP juga menganut prinsip Batas Minimum Pembuktian yang mengatur batas tentang keharusan yang dipenuhi dalam membuktikan kesalahan terdakwa.

Selain kelima alat bukti tersebut, tidak dibenarkan untuk dipergunakan dalam pembuktian kesalahan terdakwa. Alat bukti yang dibenarkan dan mempunyai kekuatan pembuktian hanyalah kelima alat bukti tersebut. Pembuktian dengan alat bukti diluar kelima alat bukti diatas, tidak mempunyai nilai serta tidak mempunyai kekuatan yang mengikat ,dalam hal ini, baik Hakim, Penuntut Umum, terdakwa maupun Penasehat Hukum, semuanya terikat pada ketentuan tata cara dan penilaian alat bukti yang ditentukan olehundang-undang. ${ }^{8}$

Hukum acara peradilan tata usaha negara dengan hukum acara peradilan pidana ada persamaan asas antara lain :

1. Dalam Hukum acara peradilan tata usaha negara yaitu dikenal asas praduga rechtmatige, dimana pejabat tata usaha negara yang mengeluarkan keputusan tata usaha negara tetap dianggaptidak bersalah dalam membuat keputusan yang digugat sebelum ada putusan hakim yang telah mempunyai kekuatan hukum tetap yang menyatakan ia bersalah. Sehingga digugatnya Keputusan Tata Usaha Negara tidak akan menyebabkan tertundanya pelaksanaan keputusan tersebut. Dalam hukum acara pidana disebut Asas presumption of innocent ( praduga tidak bersalah ), dimana asas ini menyatakan bahwaseseorang /terdakwa dianggap tidak bersalah sampai adanya putusan hakim yang mempunyai kekuatan hukum yang tetap yang menyatakan dia bersalah. 
2. Peradilan tata usaha negara juga mengenal peradilan Inabsentia ( tidak hadirnya tergugat dalam persidangan ) yang berlaku dalam Peradilan untuk Tindak Pidanakhusus.

3. Dalam hukum acara peradilan tata usaha negara yang dicari adalah kebenaran materil, dan asas ini sama dengan hukum acara pidana yaitu mencari kebenaran materil yaitu kebenaran sejati yang harus diusahakan tercapai, Makanya dalam pemeriksaan alat-alat bukti bahwa hakim kedua lembaga perdilan ini bersifat aktif dalam persidangan.

Dalam pemeriksaan alat-alat bukti perbedaan dari hukum acara peradilan tata usaha negara dengan hukum acara pidana yaitu : "Dalam pemeriksaan alat bukti bahwa hakim tidak terikat alat bukti mana yang lebih diutamakan sesuai dan jenis alat bukti yang diatur dalam Pasal 100 UUPTUN pada dasarnya mempunyai bobot yang sama sesuai dengan pasal 107 UUPTUN untuk sahnya pembuktian diperlukan sekurangkurangnya alat bukti berdasarkan keyakinan hakim. Dalam pembuktian hakim bebas menentukan alat-alat bukti yang harus diajukan para pihak. Dalam hukum acara pidana, bahwa alat bukti utama adalah keterangan saksi sesuai dengan ketentuan yang diatur dalam Pasal 295 HIR dan Pasal 184 KUHAP karena dalam suatu peristiwa pidana saksi bisa menjelaskan atau memberi keterangan sesuai dengan apa yang dilihatnya, didengarnya dan saksi juga bisa memberikan petunjuk dimana tempat kejadian peristiwapidanatersebut.

\section{PENUTUP}

Dalam pemeriksaan alat-alat bukti di persidangan Peradilan Tata Usaha Negara hampir sama dengan pemeriksaan alat-alat bukti dipersidangan Peradilan Umum dalam menyelesaikan perkara pidana, hanya sedikit perbedaan dimana dalam pemeriksaan alat bukti di Peradilan Tata Usaha negara bahwa hakim harus aktif dan hakim mempunyai kewenangan untuk menentukan siapa, apa dan bagaimana kekuatan alat-alat bukti, sedangkan di Peradilan Umum bahwa yang harus aktif dalam mengajukan alat-alat bukti adalah para pihak. Asas yang dianut dalam pembuktian di Peradilan Tata Usaha Negara adalah pembuktian bebas, dalam arti kata bahwa hakim bebas menentukan jenis-jenis alat bukti sebagaimana yang diatur dalam pasal 100 ayat (1) tetapi dalam mengambil keputusan untuk syahnya pembuktian diperlukan sekurang-kurangnya dua alat bukti 
berdasarkan keyakinan hakim. Sebagaimana yang diatur dalam Pasal 295 HIR atau Pasal 184 KUHAP dalam pemeriksaan perkara pidana di Peradilan Umum bahwa alat bukti utama yang harus diajukan alah saksi, karena keterangan saksi bisa memberikan keterangan, petunjuk tempat, waktu, penyebab peristiwa pidana tersebut.

DAFTAR PUSTAKA

Darmini Roza dan Laurensius Arliman S Peran Pemerintah Daerah Di Dalam Melindungi Hak Anak Di Indonesia, Masalah-Masalah Hukum, Volume 47, Nomor 1, 2018.

Laurensius Arliman S, Komnas HAM dan Perlindungan Anak Pelaku Tindak Pidana, Deepublish, Yogyakarta, 2015.

Laurensius Arliman S, Penguatan Perlindungan Anak Dari Tindakan Human Trafficking Di Daerah Perbatasan Indonesia, Jurnal Selat, Volume 4, Nomor 1, 2016.

Laurensius Arliman S, Problematika Dan Solusi Pemenuhan Perlindungan Hak Anak Sebagai Tersangka Tindak Pidana Di Satlantas Polresta Pariaman, Justicia Islamica, Volume 13, Nomor 2, 2016.

Laurensius Arliman S, Pelaksanaan Perlindungan Anak Yang Tereksploitasi Secara Ekonomi Oleh Pemerintah Kota Padang, Veritas et Justitia, Volume 2, Nomor 1, 2016. 
Laurensius Arliman S, Kedudukan Ketetapan MPR Dalam Hierarki Peraturan PerundangUndangan Di Indonesia, Lex Jurnalica, Volume 13, Nomor 3, 2016.

Laurensius Arliman S, Komnas Perempuan Sebagai State Auxialiary Bodies Dalam Penegakan Ham Perempuan Indonesia, Justicia Islamica, Volume 14, Nomor 2, 2017.

Laurensius Arliman S, Peranan Pers Untuk Mewujudkan Perlindungan Anak Berkelanjutan Di Indonesia, Jurnal Ilmu Hukum Tambun Bungai, Volume 2, Nomor 2, 2017.

Laurensius Arliman S, Mewujudkan Penegakan Hukum Yang Baik Untuk Mewujudkan Indonesia Sebagai Negara Hukum, Jurnal Hukum Doctrinal, Volume 2, Nomor 2, 2017.

Laurensius Arliman S, Participation Non-Governmental Organization In Protecting Child Rights In The Area Of Social Conflict, The 1st Ushuluddin and Islamic Thought International Conference (Usicon), Volume 1, 2017.

Laurensius Arliman S, Partisipasi Masyarakat Dalam Pembentukan Perundang-Undangan Untuk Mewujudkan Negara Kesejahteraan Indonesia, Jurnal Politik Pemerintahan Dharma Praja, Volume 10, Nomor 1, 2017, https://doi.org/10.33701/jppdp.v10i1.379.

Laurensius Arliman S, Peran Komisi Perlindungan Anak Indonesia Untuk Mewujudkan Perlindungan Anak, Jurnal Respublica Volume 17, Nomor 2, 2018. 
Laurensius Arliman S, Menjerat Pelaku Penyuruh Pengrusakan Barang Milik Orang Lain Dengan Mempertimbangkan Asas Fungsi Sosial, Jurnal Gagasan Hukum, Volume 1, Nomor 1, 2019.

Laurensius Arliman S, Ilmu Perundang-Undangan Yang Baik Untuk Negara Indonesia, Deepublish, Yogyakarta, 2019.

Laurensius Arliman S, Isdal Veri, Gustiwarni, Elfitrayenti, Ade Sakurawati, Yasri, Pengaruh Karakteristik Individu, Perlindungan Hak Perempuan Terhadap Kualitas Pelayanan Komnas Perempuan Dengan Kompetensi Sumber Daya Manusia Sebagai Variabel Mediasi, Jurnal Menara Ekonomi: Penelitian dan Kajian Ilmiah Bidang Ekonomi, Volume 6, Nomor 2, 2020.

Laurensius Arliman S, Pendidikan Kewarganegaraan, Deepublish, Yogyakarta, 2020.

Laurensius Arliman S, Makna Keuangan Negara Dalam Pasal Pasal 23 E Undang-Undang Dasar 1945, Jurnal Lex Librum, Volume 6, Nomor 2 Juni 2020, http://dx.doi.org/10.46839/lljih.v6i2.151.

Laurensius Arliman S, Kedudukan Lembaga Negara Independen Di Indonesia Untuk Mencapai Tujuan Negara Hukum, Kertha Semaya Journal Ilmu Hukum, Volume 8, Nomor 7, 2020. 
Laurensius Arliman S, Pelaksanaan Assesment Oleh Polres Kepulauan Mentawai Sebagai Bentuk Pelaksanaan Rehabilitasi Bagi Pecandu Dan Korban Penyalahgunaan Narkotika, Jurnal Muhakkamah, Volume 5, Nomor 1, 2020.

Laurensius Arliman S, Aswandi Aswandi, Firgi Nurdiansyah, Laxmy Defilah, Nova Sari Yudistia, Ni Putu Eka, Viona Putri, Zakia Zakia, Ernita Arief, Prinsip, Mekanisme Dan Bentuk Pelayanan Informasi Kepada Publik Oleh Direktorat Jenderal Pajak, Volume 17, No Nomor, 2020.

Larensius Arliman S, Koordinasi PT. Pegadaian (Persero) Dengan Direktorat Reserse Narkoba Polda Sumbar Dalam Penimbangan Barang Bukti Penyalahgunaan Narkotika, UIR Law Review, Volume 4, Nomor 2, 2020, https://doi.org/10.25299/uirlrev.2020.vol4(1).3779.

Laurensius Arliman S, Tantangan Pendidikan Kewarganegaraan Pada Revolusi 4.0, Ensiklopedia Sosial Review, Volume 2, Nomor 3, 2020.

Muhammad Afif dan Laurensius Arliman S, Protection Of Children's Rights Of The Islamic And Constitutional Law Perspective Of The Republic Of Indonesia, Proceeding: Internasional Conference On Humanity, Law And Sharia (Ichlash), Volume 1, Nomor 2, 2020.

Otong Rosadi danLaurensius Arliman S, Urgensi Pengaturan Badan Pembinaan Idelogi Pancasila Berdasarkan Undang-Undang Sebagai State Auxiliary Bodies yang Merawat Pancasila dalam Perspektif Hak Asasi Manusia, Prosiding Konferensi Nasional Hak Asasi 
Manusia, Kebudayaan dan Tujuan Pembangunan Berkelanjutan Indonesia pada Masa Pandemi Covid-19: Tantangan untuk Keilmuan Hukum dan Sosial Volume 1, Universitas Pancasila, Jakarta, 2020. 